Research Paper

\title{
Comprehensive analysis of interleukin-8 gene polymorphisms and periodontitis susceptibility
}

\author{
Xiao-Bing $\mathrm{Ni}^{1,}{ }^{*}$, Cheng $\mathrm{Jia}^{2, *}$, He-Dong $\mathrm{Yu}^{1,}{ }^{1}$, Yan-Qin $\mathrm{Li}^{1}$, Xian-Tao Zeng ${ }^{1}$ and Wei- \\ Dong Leng ${ }^{1}$ \\ ${ }^{1}$ Department of Stomatology, Taihe Hospital, Hubei University of Medicine, Shiyan 442000, China \\ ${ }^{2}$ Department of Orthodontics, The Third Hospital of Hebei Medical University, Shijiazhuang 050051, China \\ *These authors contributed equally to this work
}

Correspondence to: Wei-Dong Leng, email: lengtaihe@163.com

Keywords: interleukin-8, periodontitis, periodontal diseases, meta-analysis, polymorphism

Received: February 14, $2017 \quad$ Accepted: March 09, $2017 \quad$ Published: April 07, 2017

Copyright: $\mathrm{Ni}$ et al. This is an open-access article distributed under the terms of the Creative Commons Attribution License 3.0 (CC BY 3.0 ), which permits unrestricted use, distribution, and reproduction in any medium, provided the original author and source are credited.

\section{ABSTRACT}

Background: Associations between interleukin-8 (IL-8) gene polymorphisms and periodontitis susceptibility have been investigated in many published studies, but the conclusions are still inconsistent. Therefore, we performed this systematic review and meta-analysis to review which polymorphisms have been researched and to obtain a precise result of the same polymorphism from different studies.

Results: Finally 10 publications involving 1938 patients and 1569 controls were yielded, including 12 polymorphisms. Six studies investigated rs4073 polymorphism; two focused on rs2227306 and rs2227307; two referred to rs2227532 and T-738A; one detected rs2230054, rs1126579 and rs1126580; one inspected A2767T, $T_{1}$ 1722T $_{2}$ and C1633T, and one for rs2234671 polymorphism. Of them, IL-8 C1633T and rs1126580 polymorphisms showed positive association while the other ten polymorphisms revealed negative results.

Materials and methods: A comprehensive literature search from PubMed, Web of Science, and Chinese National Knowledge Infrastructure was conducted for all potentially relevant studies published before January 2, 2017. Two authors selected the studies and extracted data. The pooled analysis was conducted using the RevMan 5.1 software if a polymorphism was reported by two or more studies.

Conclusions: Based on current evidence, the IL-8 rs4073, A2767T, $\mathrm{T}_{1} \mathbf{1 7 2 2}_{2}$, rs2234671, rs2230054, rs1126579, rs2227306, rs2227307, rs2227532, and T-738A polymorphisms were not associated with periodontitis susceptibility; the IL-8 C1633T and rs1126580 polymorphisms were associated with increased risk of periodontitis.

\section{INTRODUCTION}

Interleukin (IL) plays an important role in mediating immune and inflammatory responses, and periodontitis is known as a chronic infectious disease. Hence, the genes and their variants (polymorphisms) of IL may be the important determinants of pathogenesis of periodontitis [1]. There are a large number of publications reporting the association between IL gene polymorphisms and periodontitis, some related meta-analyses have been performed for IL-1 polymorphisms [2-6], IL-4 polymorphisms [7], IL-6 polymorphisms [8], IL-10 polymorphisms [9-10], and IL-18 polymorphisms [11].
IL-8 gene is a component of IL genes with more than ten polymorphisms [12]. Numerous studies exploring the association between IL-8 gene polymorphisms and periodontitis have been published, but the results of previous studies of same polymorphism were inconsistent. Yang et al. [13] in 2016 performed a meta-analysis to investigate the effect of rs4073 (A251T/T-353A) on periodontitis susceptibility and found a positive association. The meta-analysis by Chen et al. [14] in 2015 focused on the rs4073 (A251T/T-353A) and rs2227532 (T-845C) polymorphisms which also revealed a positive association. Obviously, many other polymorphisms of IL-8 gene has not been explored, so we performed this analysis 
for further assessing the relationship between all IL-8 gene polymorphisms and periodontitis; additionally, we also reviewed which polymorphisms have been investigated. The present study followed the Preferred Reporting Items for Systematic Reviews and Meta-Analyses (PRISMA) statement [15-16].

\section{RESULTS}

\section{Study characteristics}

The initial search identified 61 publications and finally 10 articles [17-26] were included in the systematic review and meta-analysis. The literature retrieval and selection are shown in Figure 1.

The characteristics and relevant data of the included studies are shown in Table 1 and Table 2. All studies were case-control studies involving 12 polymorphisms: rs4073 (A251T/T-353A), A2767T, T 1722T , C1633T, rs2234671, rs2230054 (C785T), rs1126579 (T1208C), rs1126580 (G1440A), rs2227306 (C781T), rs2227307 (G396T), rs2227532 (T-845C), and T-738A. Eight studies focused on chronic periodontitis (CP) [17-21, 24-26]; contained $\mathrm{CP}$ and agreessive periodontitis (AgP) [22], and one only referred to $\mathrm{AgP}$ [23]. There were a total of 1938 patients and 1569 controls.

\section{rs4073 polymorphism}

Six studies [17, 22, 24-27] reported the correlation between rs4073 (A251T/T-353A) polymorphism and periodontitis. The meta-analysis based on random effect model indicated no significant association between them [T vs. A: odds ratio $(\mathrm{OR})=0.75,95 \%$ confidence interval $(\mathrm{CI})=0.51-1.11$, Figure 2 ; TA+TT vs. AA: $\mathrm{OR}=0.70$, $95 \% \mathrm{CI}=0.33-1.48$, Figure 3$)]$. The funnel plot was symmetrical (Figure 4).

\section{A2767T polymorphism}

One study [22] on A2767T polymorphism reported that it was not associated with periodontitis risk (T vs. A: $\mathrm{OR}=1.12,95 \% \mathrm{CI}=0.79-1.580, p=0.52$; TA+TT vs. $\mathrm{AA}: \mathrm{OR}=1.38,95 \% \mathrm{CI}=0.59-3.25, p=0.46)$.

\section{rs2227306 polymorphism}

Meta-analysis of two studies [21-22] showed there was no significant association between rs2227306 (C781T) polymorphism and periodontitis risk. The specific results were presented in Table 3.

\section{$T_{1}$ 1722T $_{2}$ polymorphism}

One study [22] detecting the relationship between the $T_{1} 1722 T_{2}$ polymorphism and periodontitis susceptibility suggested that there was no significant association between them $\left(\mathrm{T}_{2}\right.$ vs. $\mathrm{T}_{1}: \mathrm{OR}=17.04,95 \% \mathrm{CI}$ $=0.91-317.97, p=0.06 ; \mathrm{T}_{2} \mathrm{~T}_{1}+\mathrm{T}_{2} \mathrm{~T}_{2}$ vs. $\mathrm{T}_{1} \mathrm{~T}_{1}: \mathrm{OR}=17.35$, $95 \% \mathrm{CI}=0.93-325.33, p=0.06)$.

\section{rs2227307 polymorphism}

Table 3 showed the results of rs2227307 (G396T) polymorphism and periodontitis risk, and the metaanalysis of two studies [21-22] indicated non-significant association.

\section{C1633T polymorphism}

The results from one study [22] on C1633T polymorphism indicated that this was an increased risk of periodontitis (T vs. $\mathrm{C}: \mathrm{OR}=1.89,95 \% \mathrm{CI}=1.33-2.69$, $p<0.01$; $\mathrm{TC}+\mathrm{TT}$ vs. $\mathrm{CC}: \mathrm{OR}=3.19,95 \% \mathrm{CI}=1.85-5.51$, $p<0.01)$.

\section{rs2234671 polymorphism}

One study [20] involving rs2234671 polymorphism showed it was not related to periodontitis risk (C vs. G: $\mathrm{OR}=1.10,95 \% \mathrm{CI}=0.67-1.79, p=0.71 ; \mathrm{CG}+\mathrm{CC}$ vs. $\mathrm{GG}$ : $\mathrm{OR}=1.12,95 \% \mathrm{CI}=0.66-1.90, p=0.68)$.

\section{rs2227532 polymorphism}

Two studies $[18,25]$ reported the data for rs 2227532 (T-845C) polymorphism, and the meta-analysis displayed this polymorphism was had no significant impact on periodontitis (Table 3 ).

\section{T-738A polymorphism}

The T-738A polymorphism was evaluated by two studies $[18,25]$ and the pooled results uncovered there was non-significant association of T-738A polymorphism with periodontitis (Table 3 ).

\section{rs2230054 polymorphism}

The rs2230054 (C785T) polymorphism was assessed in one study [19] which revealed non-significant association between this polymorphism and periodontitis (T vs. $\mathrm{C}: \mathrm{OR}=1.02,95 \% \mathrm{CI}=0.79-1.32, p=0.86$; $\mathrm{TC}+\mathrm{TT}$ vs. $\mathrm{CC}: \mathrm{OR}=1.08,95 \% \mathrm{CI}=0.55-2.12, p=0.82$ ).

\section{rs1126579 polymorphism}

The rs1126579 (T1208C) polymorphism was reported by one study [19]. The results indicated that this polymorphism was not implicated in periodontitis (C vs. $\mathrm{T}: \mathrm{OR}=1.06,95 \% \mathrm{CI}=0.82-1.37, p=0.64 ; \mathrm{CT}+\mathrm{CC}$ vs. $\mathrm{TT}: \mathrm{OR}=0.84,95 \% \mathrm{CI}=0.47-1.51, p=0.56$ ). 
Table 1: Characteristics of included studies

\begin{tabular}{|c|c|c|c|c|c|c|c|}
\hline Reference & $\begin{array}{c}\text { Country } \\
\text { (ethnicity) }\end{array}$ & Type & Polymorphism & $\begin{array}{c}\text { Smoking } \\
\text { status }\end{array}$ & $\begin{array}{c}\text { Source of } \\
\text { control }\end{array}$ & $\begin{array}{l}\text { Genotyping } \\
\text { method }\end{array}$ & HWE \\
\hline Kim 2009 & Brazil (Brazilian) & $\mathrm{CP}$ & rs4073 (A251T/T-353A) & Mixed & Healthy & PCR-SSP & Yes \\
\hline Kim 2010 & Brazil (Brazilian) & $\mathrm{CP}$ & $\begin{array}{l}\text { rs2227532 } \\
\mathrm{T}-738 \mathrm{~A}\end{array}$ & Mixed & Healthy & PCR-RFLP & Yes \\
\hline Viana 2010 & Brazil (Brazilian) & $\mathrm{CP}$ & $\begin{array}{l}\text { rs2230054 } \quad(\mathrm{C} 785 \mathrm{~T}), \\
\text { rs1126579 } \quad(\mathrm{T} 1208 \mathrm{C}), \\
\text { rs1126580 }(\mathrm{G} 1440 \mathrm{~A})\end{array}$ & Mixed & Healthy & PCR-SSP & Yes \\
\hline Andia 2011 & Brazil (Brazilian) & $\mathrm{CP}$ & rs4073 (A251T) & No & Healthy & PCR & Yes \\
\hline $\begin{array}{l}\text { Scarel-Caminaga } \\
2011\end{array}$ & Brazil (Brazilian) & $\mathrm{CP}$ & $\begin{array}{l}\text { rs2227306 }(\mathrm{C} 781 \mathrm{~T}) \\
\text { rs2227307 }(\mathrm{G} 396 \mathrm{~T})\end{array}$ & Mixed & Healthy & PCR-RFLP & Yes \\
\hline $\begin{array}{l}\text { Scarel-Caminaga } \\
2011\end{array}$ & Brazil (Brazilian) & $\mathrm{CP}$ & rs2234671 & Mixed & Healthy & PCR-SSP & Yes \\
\hline Houshmand 2012 & Iran (Caucasian) & $\begin{array}{l}\mathrm{CP} \\
\text { and } \\
\mathrm{AgP}\end{array}$ & $\begin{array}{l}\text { rs4073 (A251T), A2767T, } \\
\text { C781T, T11722T2, G396T, } \\
\text { C1633T }\end{array}$ & NA & Healthy & PCR & Yes \\
\hline Andia 2013 & Brazil (Brazilian) & $\mathrm{AgP}$ & rs4073 (A251T) & No & Healthy & PCR & Yes \\
\hline $\begin{array}{l}\text { Khosropanah } \\
2013\end{array}$ & Iran (Caucasian) & $\mathrm{CP}$ & rs4073 (A251T) & No & Healthy & PCR & Yes \\
\hline Sippert 2013 & Brazil (Brazilian) & $\mathrm{CP}$ & $\begin{array}{l}\text { rs } 4073 \\
\text { rs } 2227532 \\
\text { T-738A }\end{array}$ & Mixed & Healthy & PCR-RFLP & Yes \\
\hline
\end{tabular}

AgP, aggressive periodontitis; CP, chronic periodontitis; HWE, Hardy Weinberg equilibrium; Mixed, included smokers and non-smokers; NA, not available; PCR-SSP, polymerase chain reaction- single strand polymorphism; PCR-RFLP, PCRrestriction fragment length polymorphism.

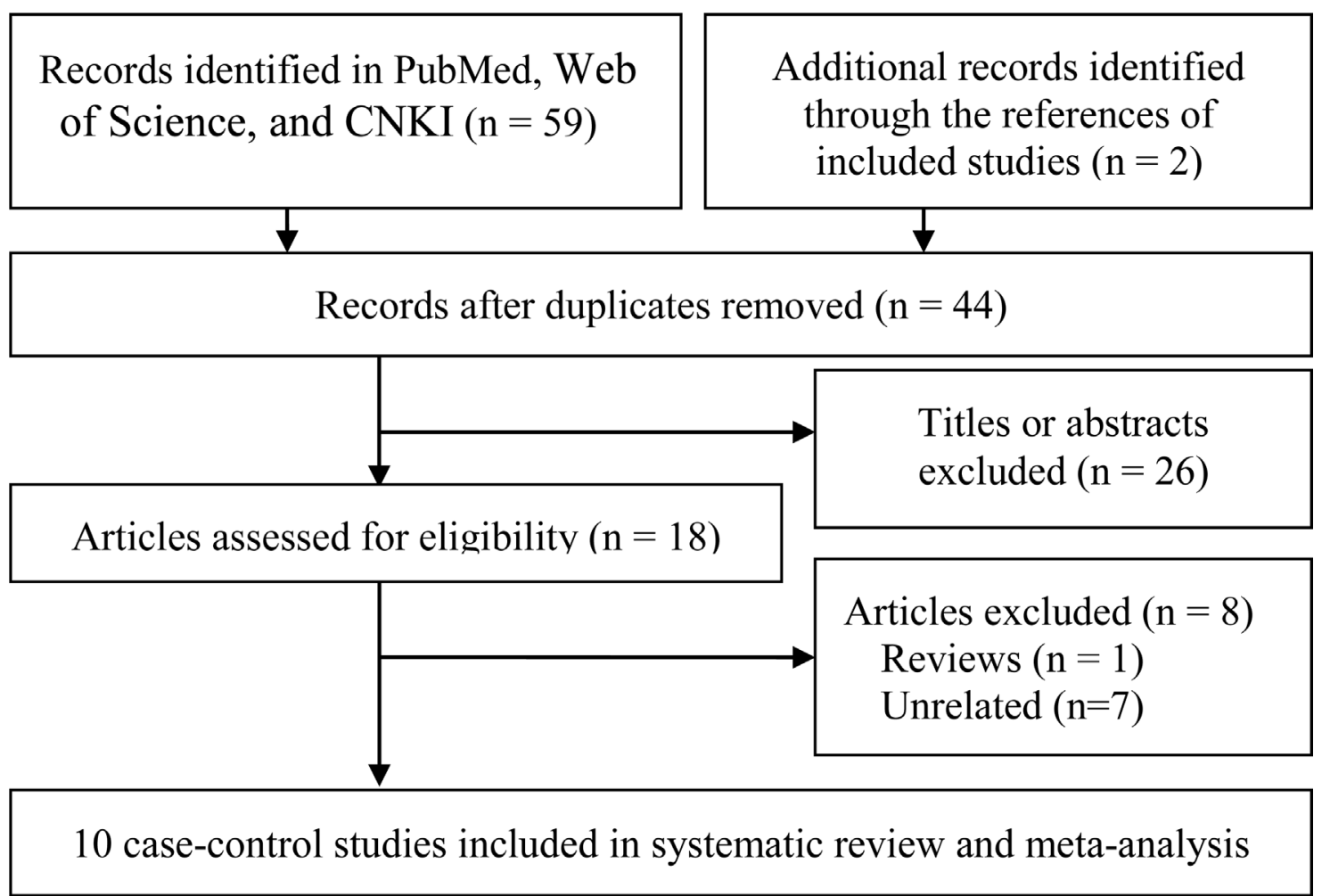

Figure 1: Study selection flow chart. 
Table 2: The data of included studies

\begin{tabular}{|c|c|c|c|c|c|}
\hline \multirow{2}{*}{$\begin{array}{l}\text { Polymorphism } \\
\text { rs4073 (A251T/T-353A) }\end{array}$} & \multirow[t]{2}{*}{ Type } & \multicolumn{4}{|c|}{ Case/Control } \\
\hline & & & & & \\
\hline & & AA & $\mathrm{TA}$ & $\mathrm{TT}$ & $\mathrm{N}$ \\
\hline Andia 2011 & $\mathrm{CP}$ & $21 / 13$ & $135 / 57$ & $25 / 38$ & $181 / 108$ \\
\hline Andia 2013 & $\mathrm{AgP}$ & $11 / 13$ & $50 / 57$ & $15 / 38$ & $76 / 108$ \\
\hline Houshmand 2012 & $\mathrm{CP}$ and $\mathrm{AgP}$ & $40 / 10$ & $55 / 120$ & $12 / 69$ & $107 / 199$ \\
\hline Sippert 2013 & $\mathrm{CP}$ & $34 / 53$ & $62 / 92$ & $28 / 42$ & $124 / 187$ \\
\hline Khosropanah 2013 & $\mathrm{CP}$ & $41 / 12$ & $101 / 17$ & $85 / 11$ & $227 / 40$ \\
\hline Kim 2009 & $\mathrm{CP}$ & $56 / 36$ & $146 / 120$ & $66 / 64$ & $268 / 220$ \\
\hline \multicolumn{6}{|l|}{ A2767T } \\
\hline & & AA & $\mathrm{AT}$ & $\mathrm{TT}$ & $\mathrm{N}$ \\
\hline \multirow{2}{*}{$\begin{array}{l}\text { Houshmand } 2012 \\
\text { rs2227306 (C781T) }\end{array}$} & $\mathrm{CP}$ and $\mathrm{AgP}$ & $8 / 20$ & $59 / 110$ & $40 / 69$ & $107 / 199$ \\
\hline & & $\mathrm{CC}$ & $\mathrm{CT}$ & TT & $\mathrm{N}$ \\
\hline Houshmand 2012 & $\mathrm{CP}$ and $\mathrm{AgP}$ & $42 / 70$ & $63 / 129$ & $2 / 0$ & $107 / 199$ \\
\hline Scarel-Caminaga 2011 & $\mathrm{CP}$ & $141 / 105$ & $112 / 96$ & $17 / 22$ & $270 / 223$ \\
\hline \multicolumn{6}{|l|}{$\mathrm{T} 11722 \mathrm{~T} 2$} \\
\hline & & $\mathrm{T} 1 \mathrm{~T} 1$ & $\mathrm{~T} 1 \mathrm{~T} 2$ & $\mathrm{~T} 2 \mathrm{~T} 2$ & $\mathrm{~N}$ \\
\hline \multirow{2}{*}{$\begin{array}{l}\text { Houshmand } 2012 \\
\text { rs2227307 (G396T) }\end{array}$} & $\mathrm{CP}$ and $\mathrm{AgP}$ & $103 / 199$ & $4 / 0$ & $0 / 0$ & $107 / 199$ \\
\hline & & GG & GT & $\mathrm{TT}$ & $\mathrm{N}$ \\
\hline Houshmand 2012 & $\mathrm{CP}$ and $\mathrm{AgP}$ & $28 / 10$ & $55 / 120$ & $24 / 69$ & $107 / 199$ \\
\hline Scarel-Caminaga 2011 & $\mathrm{CP}$ & $36 / 29$ & $120 / 125$ & $114 / 69$ & $270 / 223$ \\
\hline & \multicolumn{4}{|c|}{ C1633T } & $\mathrm{N}$ \\
\hline \multirow{2}{*}{$\begin{array}{l}\text { Houshmand } 2012 \\
\text { rs2234671 }\end{array}$} & $\mathrm{CP}$ and $\mathrm{AgP}$ & $22 / 90$ & $21 / 0$ & $64 / 109$ & $107 / 199$ \\
\hline & & GG & $\mathrm{GC}$ & $\mathrm{CC}$ & $\mathrm{N}$ \\
\hline \multirow{2}{*}{$\begin{array}{l}\text { Scarel-Caminaga } 2011 \\
\text { rs2227532 (T-845C) }\end{array}$} & $\mathrm{CP}$ & $161 / 164$ & $31 / 28$ & $3 / 3$ & $195 / 195$ \\
\hline & & $\mathrm{TT}$ & $\mathrm{TC}$ & $\mathrm{CC}$ & $\mathrm{N}$ \\
\hline Sippert 2013 & $\mathrm{CP}$ & $117 / 183$ & $6 / 4$ & $1 / 0$ & $124 / 187$ \\
\hline \multirow{3}{*}{$\begin{array}{l}\text { Kim } 2010 \\
\text { T-738A }\end{array}$} & $\mathrm{CP}$ & $137 / 127$ & $80 / 55$ & $1 / 0$ & $218 / 182$ \\
\hline & & & & & \\
\hline & & TT & TA & AA & $\mathrm{N}$ \\
\hline Sippert 2013 & $\mathrm{CP}$ & $123 / 186$ & $1 / 1$ & $0 / 0$ & $124 / 187$ \\
\hline \multirow{3}{*}{$\begin{array}{l}\text { Kim } 2010 \\
\text { rs2230054 (C785T) }\end{array}$} & & $61 / 59$ & $155 / 122$ & $2 / 1$ & $218 / 182$ \\
\hline & & & & & \\
\hline & & $\mathrm{CC}$ & CT & $\mathrm{TT}$ & $\mathrm{N}$ \\
\hline \multirow{2}{*}{$\begin{array}{l}\text { Viana } 2010 \\
\text { rs1126579 (T1208C) }\end{array}$} & $\mathrm{CP}$ & $20 / 17$ & $244 / 193$ & $8 / 5$ & $272 / 215$ \\
\hline & & $\mathrm{TT}$ & $\mathrm{TC}$ & $\mathrm{CC}$ & $\mathrm{N}$ \\
\hline \multirow{2}{*}{$\begin{array}{l}\text { Viana } 2010 \\
\text { rs1126580 (G1440A) }\end{array}$} & $\mathrm{CP}$ & $31 / 21$ & $198 / 170$ & $43 / 24$ & $272 / 215$ \\
\hline & & GG & GA & $\mathrm{AA}$ & $\mathrm{N}$ \\
\hline Viana 2010 & $\mathrm{CP}$ & $13 / 32$ & 194/119 & $65 / 64$ & $272 / 215$ \\
\hline
\end{tabular}

AgP, aggressive periodontitis; $\mathrm{CP}$, chronic periodontitis; $\mathrm{N}$, sample size. 
Table 3: Results of meta-analysis of IL-8 gene rs4037, rs2227306, rs2227307, rs2227532 and T-738A polymorphisms

\begin{tabular}{|c|c|c|c|c|c|c|c|}
\hline \multirow{2}{*}{ Polymorphism } & \multirow{2}{*}{ Genetic model } & \multirow{2}{*}{ No. } & \multicolumn{2}{|c|}{ Heterogeneity } & \multirow{2}{*}{$\begin{array}{l}\text { Effect } \\
\text { model }\end{array}$} & \multicolumn{2}{|c|}{ Meta-analysis } \\
\hline & & & $P(\%)$ & $p^{\text {h }}$ & & OR $(95 \%$ CI $)$ & $p$ \\
\hline \multirow[t]{2}{*}{ rs4073 (A251T/T-353A) } & T vs. A & 6 & 87 & $<0.01$ & Random & $0.75(0.51-1.11)$ & 0.15 \\
\hline & TA + TT vs. AA & 6 & 88 & $<0.01$ & Random & $0.70(0.33-1.48)$ & 0.35 \\
\hline \multirow[t]{2}{*}{ rs2227306 (C781T) } & T vs. C & 2 & 97 & $<0.01$ & Random & $0.44(0.10-1.99)$ & 0.29 \\
\hline & $\mathrm{TC}+\mathrm{TT}$ vs. $\mathrm{CC}$ & 2 & 0 & 0.92 & Fixed & $0.82(0.62-1.10)$ & 0.18 \\
\hline \multirow[t]{2}{*}{ rs2227307 (G396T) } & T vs. G & 2 & 94 & $<0.01$ & Random & $0.90(0.73-1.10)$ & 0.31 \\
\hline & TG + TT vs. GG & 2 & 94 & $<0.01$ & Random & $0.39(0.06-2.44)$ & 0.31 \\
\hline \multirow[t]{2}{*}{ rs2227532 (T-845C) } & C vs. T & 2 & 44 & 0.18 & Fixed & $1.41(0.99-2.01)$ & 0.06 \\
\hline & $\mathrm{CT}+\mathrm{CC}$ vs. TT & 2 & 6 & 0.3 & Fixed & $1.47(0.99-2.18)$ & 0.06 \\
\hline \multirow[t]{2}{*}{ T-738A } & A vs. $\mathrm{T}$ & 2 & 0 & 0.83 & Fixed & $1.11(0.83-1.49)$ & 0.46 \\
\hline & AT + AA vs. TT & 2 & 0 & 0.89 & Fixed & $1.24(0.81-1.89)$ & 0.32 \\
\hline
\end{tabular}

No., number of studies; CI, confidence interval; OR, odds ratio.

\section{rs1126580 polymorphism}

The results from one study [19] demonstrated that rs1126580 (G1440A) polymorphism might be associated with the increased risk of periodontitis $(\mathrm{AG}+\mathrm{AA}$ vs. GG: $\mathrm{OR}=3.48,95 \% \mathrm{CI}=1.78-6.82, p<0.01)$.

\section{DISCUSSION}

IL-8 gene located on chromosome 4q12-21 contains four exons and three introns which possesses many functional polymorphisms $[12,28]$. Published meta-analyses indicate that IL-8 gene polymorphisms are associated with some diseases, such as gastric cancer [29], oral cancer [30], and peptic ulcer disease [31]. The first study assessing IL-8 rs4037 polymorphism and periodontitis was published by Kim et al. [17] in 2011. Our systematic review and meta-analysis included 10 publications involving 3507 individuals, investigating the correlations between 12 polymorphisms of IL-8 gene and periodontitis. The results showed that the IL-8 rs4073 (A251T/T-353A), A2767T, T1 1722T 2 , rs2234671, rs2230054 (C785T), rs1126579 (T1208C), rs2227306 (C781T), rs2227307 (G396T), rs2227532 (T-845C), and T-738A polymorphisms were not significantly related to periodontitis susceptibility; however, there was a significant difference in the IL-8 C1633T and rs 1126580 (G1440A) polymorphisms between the periodontitis patients and healthy control groups.

Compared with published two meta-analyses [13-14] on this topic, the major strength of our study is that it is the first comprehensive meta-analysis on IL-8 gene polymorphisms and periodontitis risk. We believe it gives a useful summary of current data regarding the relationship between IL-8 gene polymorphisms and periodontitis risk, and provides improved clinical clarity to obtain a solid evidence base for the diagnosis and treatment of periodontitis. As to the included studies, sample size for each polymorphism was very small, so the relevant researches are suggested to be conducted in the future. Since there are more than 15 polymorphisms of IL-8 gene have been characterized [29], the association between additional polymorphisms and risk of periodontitis should be investigated. The $\mathrm{AgP}$ and $\mathrm{CP}$ are

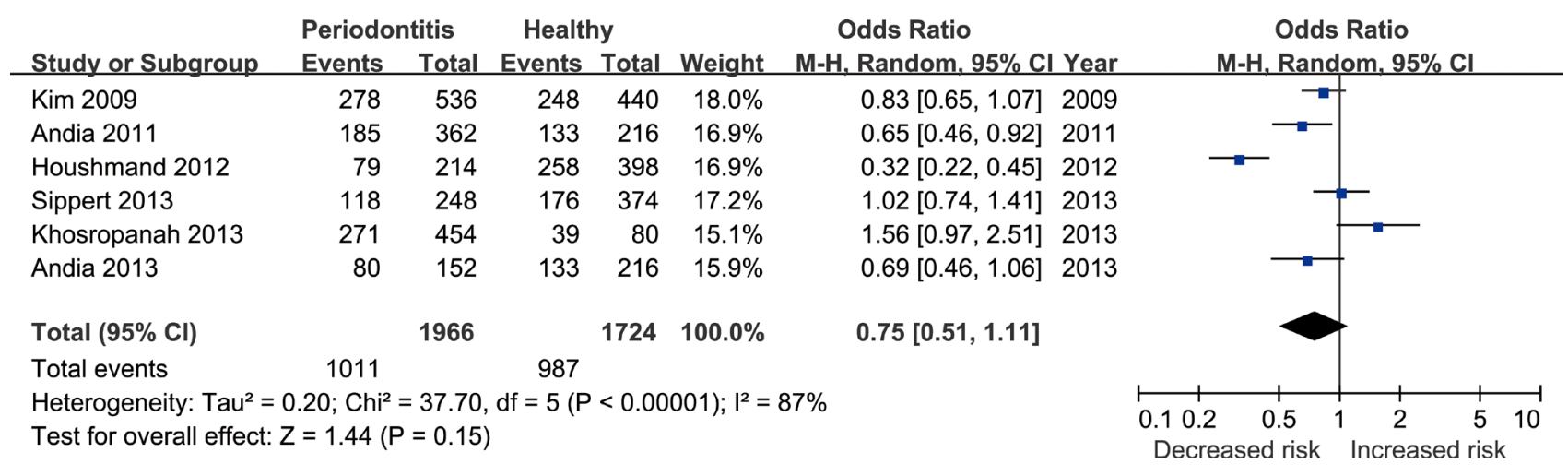

Figure 2: Forest plot for the T vs. A genetic model in IL-8 rs4073 polymorphism. 
two different types of periodontitis and the former type is considered as a genetically inherited disease [2, 32]. Hence, the further studies should report the data for $\mathrm{CP}$ and AgP separately.

The major limitation of our study was the numbers of included studies and sample size. Of these 12 polymorphisms, only IL-8 rs4073 polymorphism was involved in 6 studies while the others referred to one or two studies. Correspondingly, the sample size for each polymorphism was relatively small, which restrained the confidence of current results. Moreover, the subgroup analyses based on difference between ethnicity, smoking status, type of periodontitis, or other factors couldn't be conducted to investigate the source of heterogeneity, which might bias the results. Because of the limited numbers of included studies, we only assessed the publication bias of those investigating the IL-8 rs4073 polymorphism. Secondly, systematic review and metaanalysis is an observational study which was restricted by the quality of primary studies $[6,16,33-35]$. Although we had conducted a more comprehensive search, our study could not escape from this limitation. Lastly, our results were based on unadjusted data and the original data were sufficient, hence the evaluation of the effects of the gene - gene or gene - environment interactions was neglected. These limitations mentioned above might affect our final conclusions.

In conclusion, our meta-analysis suggests that the IL-8 rs4073, A2767T, $\mathrm{T}_{1} 1722 \mathrm{~T}_{2}$, rs2234671, rs2230054, rs1126579, rs2227306, rs2227307, rs2227532, and T-738A polymorphisms are not associated with periodontitis while the IL-8 C1633T and rs1126580 polymorphisms may elevate the susceptibility of periodontitis based on the currently available evidences. However, for considering that the studies included in our meta-analysis were based on small numbers, the current results should be treated with caution, and the results may change with the larger sample size in future. Due to these limitations, more well designed, studies with larger sample size, and adjusted risk factors are required to further validate our results.

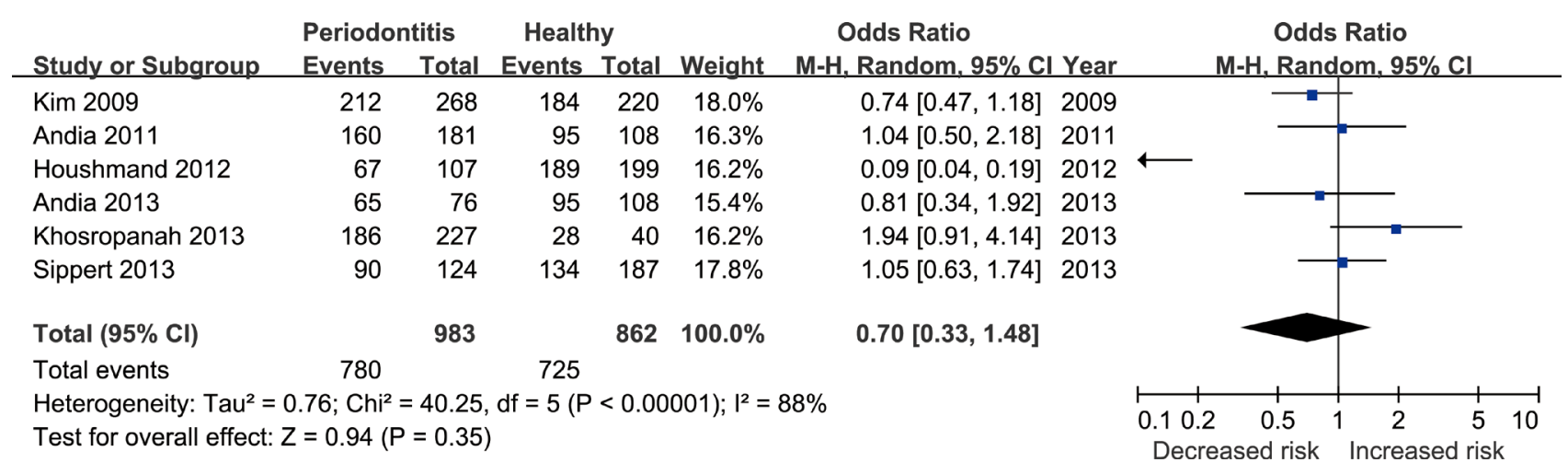

Figure 3: Forest plot for the TA+TT vs. AA genetic model in IL-8 rs4073 polymorphism.

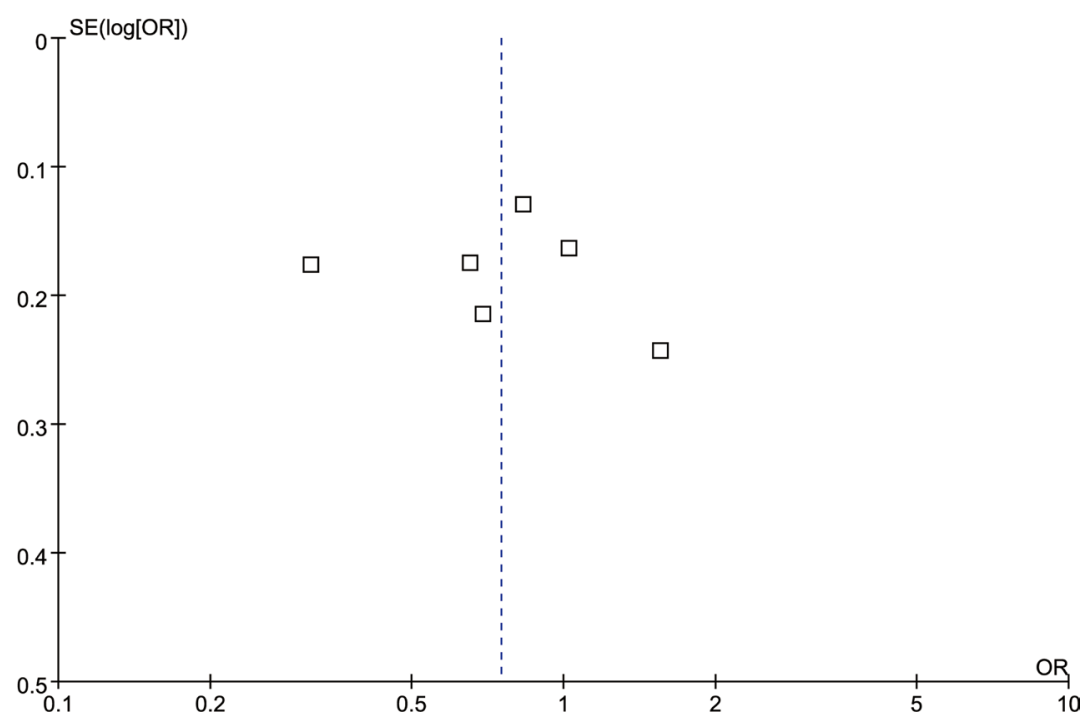

Figure 4: Funnel plot for the T vs. A genetic model in IL-8 rs4073 polymorphism. 


\section{MATERIALS AND METHODS}

\section{Eligible criteria}

We included the studies which met all of the following criteria: (1) the patients were clearly diagnosed as periodontitis ( $\mathrm{CP}$ and/or $\mathrm{AgP})$ and the controls were periodontitis-free or periodontal healthy; (2) at least one of the IL-8 polymorphisms and periodontitis susceptibility were evaluated, using a case-control or cohort study design; (3) the studies reported full data for necessary genotypes in each group or contained sufficient data to calculate them. If the same institute published two or more publications, we treated them as independent ones and chose the more comprehensive one.

\section{Search strategy}

A comprehensive literature search was performed in PubMed, Web of Science, and Chinese National Knowledge Infrastructure (CNKI) up to January 2, 2017. The following key words were used: IL-8, interleukin-8, interleukin 8 , periodontal disease, periodontitis, variant, and polymorphism. Moreover, all listed references of included studies and recently reviews were retrieved for any additional relevant studies. No language restriction was applied in the search process.

\section{Data extraction}

Study selection and data extraction were performed by two authors and any discrepancy was resolved by discussion. The following data were extracted from each included study: surname of first author, year of publication, study design, country and ethnicity of study population, demographics, periodontitis type, smoking status, number of cases and controls, polymorphism, genotype distribution, source of controls, genotyping method, and Hardy-Weinberg equilibrium (HWE) for controls.

\section{Data analysis}

The OR and its $95 \%$ CI were calculated to estimate the relationship between the IL-8 polymorphisms and periodontitis risk. All studies used a allele genetic model and a dominant genetic model [5]. If a polymorphism was reported in two or more studies, a meta-analysis was conducted. Heterogeneity was assessed using the Cochran's $Q$ statistic and $I^{2}$ statistic $[15,36]$, with values of $P \geq 0.1$ and $I^{2}<50 \%$ indicating acceptable heterogeneity. If no significant heterogeneity existed, the fixed effect model was used; otherwise, the random-effects model was used. If the number of included studies was available, we conducted subgroup analyses on the ethnicity, smoking status, and periodontitis type. Publication bias was assessed by funnel plot [37]. All analyses were performed using RevMan 5.1 software [38-39].

\section{CONFLICTS OF INTEREST}

The authors declare no conflicts of interest.

\section{GRANT SUPPORT}

This research was supported (in part) by the Foundation of Evidence-based Medicine Nursery Fund of Taihe Hospital (EBM2013028 and EBM2014007), without commercial or not-for-profit sectors. The funders had no role in study design, data collection and analysis, decision to publish, or preparation of the manuscript. No additional external funding received for this study. We also wish to thank relevant editors and peer-reviewers for their hard work and suggestions.

\section{REFERENCES}

1. Laine ML, Crielaard W, Loos BG. Genetic susceptibility to periodontitis. Periodontol 2000. 2012; 58:37-68. https://doi. org/10.1111/j.1600-0757.2011.00415.x.

2. Wang WF, Shi J, Chen SJ, Niu YM, Zeng XT. Interleukin1alpha -899 (4845) C $\longrightarrow$ T polymorphism is not associated with aggressive periodontitis susceptibility: A meta-analysis based on 19 case-control studies. Biomed Rep. 2014; 2:378-83. https://doi.org/10.3892/br.2014.240.

3. Mao M, Zeng XT, Ma T, He W, Zhang C, Zhou J. Interleukin-1alpha -899 (4845) $\mathrm{C} \longrightarrow \mathrm{T}$ polymorphism increases the risk of chronic periodontitis: evidence from a meta-analysis of 23 case-control studies. Gene. 2013; 532:114-9. https://doi.org/10.1016/j.gene.2013.09.043.

4. Deng JS, Qin P, Li XX, Du YH. Association between interleukinlbeta C (3953/4)T polymorphism and chronic periodontitis: evidence from a meta-analysis. Hum Immunol. 2013; 74:371-8. https://doi.org/10.1016/j.humimm.2012.11.018.

5. Karimbux NY, Saraiya VM, Elangovan S, Allareddy V, Kinnunen T, Kornman KS, Duff GW. Interleukin-1 gene polymorphisms and chronic periodontitis in adult whites: a systematic review and meta-analysis. J Periodontol. 2012; 83:1407-19. https://doi.org/10.1902/jop.2012.110655.

6. Huang W, He BY, Shao J, Jia XW, Yuan YD. Interleukin-1 $\beta$ rs1143627 polymorphism with susceptibility to periodontal disease. Oncotarget. 2017; 8:31406-31414. https://doi. org/10.18632/oncotarget.15612.

7. Yan Y, Weng H, Shen ZH, Wu L, Zeng XT. Association between interleukin-4 gene $-590 \mathrm{c} / \mathrm{t},-33 \mathrm{c} / \mathrm{t}$, and 70-basepair polymorphisms and periodontitis susceptibility: a meta-analysis. J Periodontol. 2014; 85:e354-62. https://doi. org/10.1902/jop.2014.140317.

8. Shao MY, Huang $\mathrm{P}$, Cheng $\mathrm{R}$, $\mathrm{Hu} \mathrm{T}$. Interleukin-6 polymorphisms modify the risk of periodontitis: a 
systematic review and meta-analysis. J Zhejiang Univ Sci B. 2009; 10:920-27. https://doi.org/10.1631/jzus. B0920279.

9. Albuquerque $\mathrm{CM}$, Cortinhas $\mathrm{AJ}$, Morinha FJ, Leitão JC, Viegas CA, Bastos EM. Association of the IL-10 polymorphisms and periodontitis: a meta-analysis. Mol Biol Rep. 2012; 39:9319-29. https://doi.org/10.1007/s11033012-1738-1.

10. Zhong Q, Ding C, Wang M, Sun Y, Xu Y. Interleukin-10 gene polymorphisms and chronic/aggressive periodontitis susceptibility: a meta-analysis based on 14 case-control studies. Cytokine. 2012; 60:47-54. https://doi.org/10.1016/j. cyto.2012.05.014.

11. Li ZG, Li JJ, Sun CA, Jin Y, Wu WW. Interleukin-18 promoter polymorphisms and plasma levels are associated with increased risk of periodontitis: a meta-analysis. Inflamm Res. 2014; 63:45-52. https://doi.org/10.1007/ s00011-013-0669-1.

12. Bickel M. The role of interleukin- 8 in inflammation and mechanisms of regulation. J Periodontol. 1993 (Suppl); 64:456-60.

13. Yang ZJ, Tang XP, Lai QG, Ci JB, Yuan KF. Interleukin-8 $-251 \mathrm{~A} / \mathrm{T}$ polymorphism and periodontitis susceptibility: a meta-analysis. Genet Mol Res. 2016; 15. https://doi. org/10.4238/gmr15047379.

14. Chen X, Huang J, Zhong L, Ding C. Quantitative assessment of the associations between interleukin- 8 polymorphisms and periodontitis susceptibility. J Periodontol. 2015; 86:292-300. https://doi.org/10.1902/jop.2014.140450.

15. Moher D, Liberati A, Tetzlaff J, Altman DG, Group P. Preferred reporting items for systematic reviews and metaanalyses: the PRISMA statement. BMJ. 2009; 339:b2535. https://doi.org/10.1136/bmj.b2535.

16. Zhai Y, Dai Z, He H, Gao F, Yang L, Dong Y, Lu J. A PRISMA-compliant meta-analysis of MDM4 genetic variants and cancer susceptibility. Oncotarget. 2016; 7:73935-44. https://doi.org/10.18632/oncotarget.12558.

17. Kim YJ, Viana AC, Curtis KM, Orrico SR, Cirelli JA, Scarel-Caminaga RM. Lack of association of a functional polymorphism in the interleukin 8 gene with susceptibility to periodontitis. DNA Cell Biol. 2009; 28:185-90. https:// doi.org/10.1089/dna.2008.0816.

18. Kim YJ, Viana AC, Curtis KM, Orrico SR, Cirelli JA, Mendes-Junior CT, Scarel-Caminaga RM. Association of haplotypes in the IL8 gene with susceptibility to chronic periodontitis in a Brazilian population. Clin Chim Acta. 2010; 411:1264-8. https://doi.org/10.1016/j.cca.2010.05.014.

19. Viana AC, Kim YJ, Curtis KM, Renzi R, Orrico SR, Cirelli JA, Scarel-Caminaga RM. Association of haplotypes in the CXCR2 gene with periodontitis in a Brazilian population. DNA Cell Biol. 2010; 29:191-200. https://doi. org/10.1089/dna.2009.0919.

20. Scarel-Caminaga RM, Curtis KM, Renzi R, Sogumo PM, Anovazzi G, Viana AC, Kim YJ, Orrico SR, Cirelli JA.
Variation in the CXCR1 gene (IL8RA) is not associated with susceptibility to chronic periodontitis. J Negat Results Biomed. 2011; 10:14. https://doi. org/10.1186/1477-5751-10-14.

21. Scarel-Caminaga RM, Kim YJ, Viana AC, Curtis KM, Corbi SC, Sogumo PM, Orrico SR, Cirelli JA. Haplotypes in the interleukin 8 gene and their association with chronic periodontitis susceptibility. Biochem Genet. 2011; 49:292-302. https://doi.org/10.1007/s10528-010-9407-3.

22. Houshmand B, Hajilooi M, Rafiei A, Bidgoli M, Soheilifar S. Evaluation of IL-8 gene polymorphisms in patients with periodontitis in Hamedan, Iran. Dent Res J (Isfahan). 2012; 9:427-32.

23. Andia DC, Letra A, Casarin RC, Casati MZ, Line SR, de Souza AP. Genetic analysis of the IL8 gene polymorphism (rs4073) in generalized aggressive periodontitis. Arch Oral Biol. 2013; 58:211-7. https://doi.org/10.1016/j. archoralbio.2012.05.008.

24. Khosropanah H, Sarvestani EK, Mahmoodi A, Golshah M. Association of IL-8 (-251 a/t) gene polymorphism with clinical parameters and chronic periodontitis. J Dent (Tehran). 2013; 10:312-18.

25. Sippert EA, de Oliveira e Silva C, Visentainer JE, Sell AM. Association of duffy blood group gene polymorphisms with IL8 gene in chronic periodontitis. PLoS One. 2013; 8:e83286. https://doi.org/10.1371/journal.pone.0083286.

26. Andia DC, de Oliveira NF, Letra AM, Nociti FH Jr, Line SR, de Souza AP. Interleukin-8 gene promoter polymorphism (rs4073) may contribute to chronic periodontitis. J Periodontol. 2011; 82:893-99. https://doi. org/10.1902/jop.2010.100513.

27. Kalischuk LD, Inglis GD. Comparative genotypic and pathogenic examination of Campylobacter concisus isolates from diarrheic and non-diarrheic humans. BMC Microbiol. 2011; 11:53. https://doi.org/10.1186/1471-2180-11-53.

28. Hull J, Rowlands K, Lockhart E, Sharland M, Moore C, Hanchard N, Kwiatkowski DP. Haplotype mapping of the bronchiolitis susceptibility locus near IL8. Hum Genet. 2004; 114:272-79. https://doi.org/10.1007/s00439-003-1038-x.

29. Cheng D, Hao Y, Zhou W, Ma Y. Positive association between Interleukin-8 -251A > T polymorphism and susceptibility to gastric carcinogenesis: a meta-analysis. Cancer Cell Int. 2013; 13:100. https://doi.org/10.1186/14752867-13-100.

30. Wang Z, Wang C, Zhao Z, Liu F, Guan X, Lin X, Zhang L. Association between $-251 \mathrm{~A}>\mathrm{T}$ polymorphism in the interleukin- 8 gene and oral cancer risk: a meta-analysis. Gene. 2013; 522:168-76. https://doi.org/10.1016/j. gene.2013.03.066.

31. Yin YW, Hu AM, Sun QQ, Zhang BB, Wang Q, Liu HL, Zeng $\mathrm{YH}, \mathrm{Xu}$ RJ, Zhang SJ, Shi LB. Association between interleukin-8 gene -251 T/A polymorphism and the risk of peptic ulcer disease: a meta-analysis. Hum 
Immunol. 2013; 74:125-30. https://doi.org/10.1016/j. humimm.2012.09.006.

32. Hart TC, Pallos D, Bozzo L, Almeida OP, Marazita ML, O'Connell JR, Cortelli JR. Evidence of genetic heterogeneity for hereditary gingival fibromatosis. J Dent Res. 2000; 79:1758-64. doi https://doi.org/10.1177/00220 345000790100501 PMID:11077991.

33. Zeng X, Zhang Y, Kwong JS, Zhang C, Li S, Sun F, Niu Y, $\mathrm{Du}$ L. The methodological quality assessment tools for preclinical and clinical studies, systematic review and meta-analysis, and clinical practice guideline: a systematic review. J Evid Based Med. 2015; 8:2-10. https://doi. org/10.1111/jebm.12141.

34. Zeng XT, Liu DY, Kwong JS, Leng WD, Xia LY, Mao M. Meta-Analysis of Association Between Interleukin$1 \beta$ C-511T Polymorphism and Chronic Periodontitis Susceptibility. J Periodontol. 2015; 86:812-19. https://doi. org/10.1902/jop.2015.140698.

35. Zeng XT, Leng WD, Lam YY, Yan BP, Wei XM, Weng H, Kwong JS. Periodontal disease and carotid atherosclerosis: A meta-analysis of 17,330 participants. Int J Cardiol. 2016; 203:1044-51. https://doi.org/10.1016/j.ijcard.2015.11.092.
36. Higgins JP, Thompson SG, Deeks JJ, Altman DG. Measuring inconsistency in meta-analyses. BMJ. 2003; 327 : 557-60. https://doi.org/10.1136/bmj.327.7414.557.

37. Egger M, Davey Smith G, Schneider M, Minder C. Bias in meta-analysis detected by a simple, graphical test. BMJ. 1997; 315:629-34. doi https://doi.org/10.1136/ bmj.315.7109.629PMID:9310563.

38. Leng WD, Wen XJ, Kwong JS, Huang W, Chen JG, Zeng XT. COX-2 rs689466, rs5275, and rs20417 polymorphisms and risk of head and neck squamous cell carcinoma: a metaanalysis of adjusted and unadjusted data. BMC Cancer. 2016; 16:457. https://doi.org/10.1186/s12885-016-2535-3.

39. Zeng XT, Xia LY, Zhang YG, Li S, Leng WD, Kwong JS. Periodontal Disease and Incident Lung Cancer Risk: A Meta-Analysis of Cohort Studies. J Periodontol. 2016; 87:1158-64. https://doi.org/10.1902/jop.2016.150597. 